OPEN ACCESS

Manuscript ID:

EDU-2021-09033989

Volume: 9

Issue: 3

Month: June

Year: 2021

P-ISSN: 2320-2653

E-ISSN: 2582-1334

Received: 07.04.2021

Accepted: 18.05.2021

Published: 01.06.2021

Citation:

Imsa-ard, Pariwat, et al.

"Muffled Voices from

Thai Pre-Service Teachers: Challenges and Difficulties during Teaching Practicum." Shanlax International Journal of Education, vol. 9, no. 3, 2021, pp. 246-260.

DOI:

https://doi.org/10.34293/ education.v9i3.3989

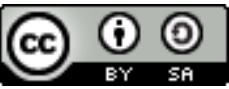

This work is licensed under a Creative Commons Attribution-ShareAlike 4.0 International License

\section{Muffled Voices from Thai Pre-Service Teachers: Challenges and Difficulties during Teaching Practicum}

\author{
Pariwat Imsa-ard \\ Faculty of Education, Ramkhamhaeng University, Bangkok, Thailand
}

Peerada Wichamuk

Faculty of Education, Ramkhamhaeng University, Bangkok, Thailand

\author{
Chain Chuanchom \\ Faculty of Education, Ramkhamhaeng University, Bangkok, Thailand
}

\begin{abstract}
The study aimed at exploring the perceptions pre-service student teachers had about their challenges and difficulties that hindered their teaching. The present study espoused a convergent mixed-methods approach, which adopted a questionnaire and semi-structured focused-groupinterviews as the research instruments. The participants of this small-scale study were B.Ed. Students at a university in Thailand. There were 78 participants in a quantitative phase, while 17 of them participated in a semi-structured-focus-group interview. The findings demonstrated around 4 dimensions of various constraints and challenges. This embodied: communication factors, instructional factors, student-related factors, and support-related factors. Based on OneWay ANOVA, most students appeared to face similar challenges. However, pre-service student teachers at early childhood and primary school levels highlighted the different challenges which they encountered during their practicum experience concerning various teaching methods used in their lessons. The findings also addressed some areas which needed improvement in the teacher education program. Recommendations were suggested to enhance practical and effective teacher education among future teachers in Thailand.
\end{abstract}

Keywords: Teacher education, Student teachers, Teaching practicum, Pre-service teachers

\section{Introduction}

Teaching practice, or teaching practicum, has come to be recognized as one of the most significant aspects of the teacher education program. It is indisputable that teaching practicum has been one of the most significant components and lies at the heart of the teacher development process with a great impact on teacher quality (Zeicher, 2010). Much research examining pre-service teachers' practicum reveals that the practicum component of a pre-service training program has a crucial impact on their future careers (Myles, et al., 2006; Rozelle \& Wilson, 2012). Likewise, this is consistent with The Association of Teachers and Lecturers (2015) contention that $76 \%$ of trainees say they have considered leaving teaching because of stress, disappointment and problems arising during their teaching practicum to leave them with bad nightmares of being a teacher. Accordingly, detecting the challenges and difficulties experienced by preservice student teachers could lead to a feasible way to better the quality of the practicum and build positive attitudes towards teaching careers. Such practices could lead to a well-designed teaching practicum, which ensures that teacher training programs can produce high-quality teachers for society. 
Recently, there has been a growing realization to improve teacher education programs to ensure that pre-service student teachers undergo effective teaching practicum as part of their teacher education programs. Despite a considerable amount of evidence of studies on teacher learning in general (e.g., Allen, 2009; Graham \& Thornley, 2000; O’Neill \& Stephenson, 2012), there is a paucity of research studies conducted on what exactly takes place during the practicum experiences undertaken by preservice student teachers (Mudra, 2018). Moreover, studies focusing on pre-service teachers' practicum experience in Thailand have been comparatively limited. In response to this research gap, this study aims to gather information on the challenges and difficulties pre-service EFL teachers experience in their teaching practicum to help improve the quality of the teacher education program in Thailand. This increased attention to challenges faced by pre-service student teachers is believed to create empirical research for developments in teacher education programs.

\section{Literature Review \\ Teaching Practicum}

Teaching practicum is fundamental to preservice teachers' professional development, as it can shape their beliefs and perceptions towards teaching. Wilson (2006) demonstrates that pre-service student teachers considered teaching practicum one of the essential components of teacher education. In teacher education programs, including the ones in Thailand, teaching practicum is one of the compulsory courses before their graduation. In teaching practicum, preservice student teachers can learn by first observing their school mentor as an expert and then teaching through hands-on experience. Moreover, having pre-service student teachers in the field practice can allow them to make some connections between theories learned and practice.

However, joining teaching practicum can be the worst nightmare for many pre-service student teachers with an assumption that they are new in the profession (Yunus et al., 2010; Pushkin, 2001). As teaching practicum is considered the first time that pre-service student teachers have the opportunity to practically experiment with their theories and knowledge in real practice, several challenges and difficulties are expected to arise. If such challenges are not addressed, they could aggravate more problems, particularly to the quality of teaching and learning activities which affects the quality of education. Sammephet and Wanphet (2013) also demonstrate that the first classroom encounter is considered a challenge for pre-service student teachers which is a possible cause of anxiety. Hence, identifying what causes horrible feelings during a teaching practicum can help in enhancing teacher education programs. With this concern, a considerable amount of research suggests the need to pay close attention to challenges for future development in teacher education programs.

\section{Related Studies}

To date, there have been several research studies investigating the challenges faced by pre-service student teachers in many contexts. To begin with, Jusoh (2011), investigating the problems faced by pre-service student teachers in Malaysia through indepth interviews, discovered that they faced several challenges concerning themselves and teaching. In addition, Hammad (2005) exploring the reality of practicum from 134 students in Gaza revealed that one of the factors affecting their teaching practicum experience was related to academic supervisors. Also, Ong (2004) discovered some challenges that burden the pre-service student teachers, including supervision and pedagogical knowledge and content knowledge. To support this, Gan (2013) also revealed that pre-service student teachers had some difficulty in experimenting with pedagogical/instructional practices and managing the classes.

In addition, Kabilan and Izzaham (2008), exploring challenges faced by Malaysian preservice student teachers, found that pre-service student teachers appeared to have challenges with students, especially in mixed ability classes. Furthermoer, Copland et al., (2014) and Prihatin et al., (2021) found that class sizes that are large are a common challenge faced by many teachers worldwide, resulting in difficulties to manage to class. Moreover, Smith and Lev-Ari (2005) revealed that pre-service student teachers did not perceive school principals as supportive during their teaching 
practice. Not only were school principals reported as challenges in previous studies, but school mentors were also reported as their concerns in several studies. For instance, Hastings (2004) and Sağlam (2007) investigated the challenges and perceptions towards teaching practicum and found that support, especially from mentors, plays an important role in teaching practicum.

Even though there are many studies that have investigated challenges faced by pre-service student teachers in various countries globally, scant attention has been paid to how Thai pre-service student teachers survived in their teaching practicum in Thailand. To fill this gap, the following research questions were formed to guide this study:

- What are the problems or challenges Thai preservice student teachers experience during their teaching practicum?

- Are there statistical differences of pre-service teachers' challenges and difficulties related to their teaching levels (i.e., early childhood, primary school, and secondary school levels)?

\section{Methodology}

\section{Research Design}

The aim of this study is to investigate what challenges and difficulties pre-service student teachers in Thailand are facing during their teaching practicum. A convergent mixed-methods design was espoused to compare quantitative and qualitative data (Creswell \& Creswell, 2018). This study was divided into two phases: the survey phase and the interview phase. In a quantitative phase, the exploratory survey determined overall challenges and difficulties during a teaching practicum. In a qualitative phase, moreover, interviews offered Thai pre-service teachers in-depth views concerning the challenges and difficulties they encountered during their teaching practicum.

\section{Research Context}

After three years of coursework, teaching practicum takes place in the fourth year of study. Upon graduation, pre-service student teachers are expected to complete their 2-semester teaching practicum at schools hoping that they will be able to relate and interrogate their coursework knowledge and theories into practice. In the teacher education program, there are three different levels of teaching, i.e., early childhood, primary school, and secondary school levels. During teaching practicum, university supervisors are expected to visit each pre-service teacher at least 4 times per semester. In a visit, the supervisors observe pre-service student teachers and hold post-observation meetings with each of them as part of the assessment of teaching practicum.

\section{Participants}

The participants in this research are 78 Thai preservice student teachers who have enrolled in the Bachelor of Education degree program at a public university in Thailand. All the participants are in their final year of the Bachelor of Education degree, which is the period of their teaching practicum. The preservice student teachers could describe their hands-on experiences and challenges without any restriction. All of 78 completed the quantitative questionnaire, \& 17 of them participated in qualitative semi-structured interviews. In a quantitative phase, snowball sampling was adopted to reach the participants. In a qualitative phase, purposive sampling was employed to seek Thai pre-service teachers. It is a common practice in qualitative research and sampling occurs deliberately with the focus of the research in mind (Maxwell, 1997; Punch, 2009). In addition, Patton (1990) demonstrates that "the logic and power of purposive sampling lies in selecting information-rich cases for study".

Table 1: General Information of the Participants

\begin{tabular}{|c|c|}
\hline Information & Numbers \\
\hline \multicolumn{2}{|c|}{ Gender } \\
\hline Female & $63(80.80 \%)$ \\
\hline Male & $11(14.10 \%)$ \\
\hline Prefer not to say & $4(5.10 \%)$ \\
\hline \multicolumn{2}{|c|}{ Teaching Levels } \\
\hline Early Childhood & $20(25.60 \%)$ \\
\hline Primary school & $19(24.40 \%)$ \\
\hline Secondary school & $39(50.00 \%)$ \\
\hline
\end{tabular}

As seen in Table 1, the participants involved in this study consisted of $63(80.80 \%)$ females, $11(14.10 \%)$ males, and $4(5.10 \%)$ students who preferred not to indicate their gender. In terms of a gender imbalance, 
the possible reason for this phenomenon is that the total number of female students is higher than male students according to the National Statistical Office (2019); therefore, the responses were likely to be received from more female students than male students. Concerning the teaching levels, there were $20(25.60 \%)$, pre-service student teachers, teaching at the early childhood level, 19 (24.40\%) pre-service student teachers teaching at the primary school level, and 39 (50.00\%) pre-service student teachers teaching at the secondary school level.

\section{Research Instruments}

As this study used a convergent mixed-methods design, the questionnaire and interview questions were employed as research instruments. In this research study, questionnaire items were adopted and developed from Gujjar et al., (2011), Ragawanti (2015), and Ulla (2016). In this questionnaire, there were 26 items and an additional open-ended question. This questionnaire's items were developed through a system of translation into Thai to avoid ambiguity and mistranslation, piloting and consultation with lecturers in teacher education. Some items were omitted based on their suitability in a Thai context.

In addition to a questionnaire, the semistructure-focused-group interview was used in this study. Interviews afforded depth of data because participants were encouraged to reflect, discuss and share their thoughts, beliefs and experiences (Denzin $\&$ Lincoln, 2003). The interview questions were adopted and developed from Blaik Houran (2013) and Ulla (2016). The interview questions were to steer the conversation and cover the various aspects ascertained in the research question as follows:

- How was your teaching practicum?

- Were there any obstacles or difficulties during your teaching practicum? Share some.

- What would you recommend to improve our teacher education program?

\section{Reliability and Validity of Research Instruments}

The reliability of the questionnaire items was evaluated through a pilot study. In the pilot study, 8 Thai pre-service students were randomly chosen from the same target population. The item reliability was evaluated through the reliability coefficient test with Cronbach Alpha. Concerning the reliability of overall questionnaire items, the value of Cronbach Alpha was 0.805 , showing acceptable consistency of reliability.

Measuring the validity of the questionnaire items and interview schedules, three experts in teacher education were asked to evaluate the validity and give comments on the questionnaire items and interview schedules. Moreover, the questionnaire items and the interview questions were translated into Thai with help from two experts in Thai-English translation to avoid misunderstanding and misinterpretation. Hence, all the experts and translators responded that the questionnaire items and interview questions were valid to explore the research question.

\section{Data Collection}

To collect data for this study, the questionnaire was administered to gather overall information and the semi-structured-focus-group interviews were conducted to gather rich and detailed data and to engage participants in telling their stories (Denzin \& Lincoln, 2000; Mukminin, 2012). First, the questionnaire was administered online through a google form. The link was sent to Thai pre-service student teachers at a university where research was conducted using snowball sampling. Also, another research tool employed for this study is semistructured-focused-group interviews (4-6 pre-service student teachers for 30-45 minutes). The participants in semi-structured-focused-group interviews were chosen based on purposive sampling. Patton (1990) demonstrates "the logic and power of purposive sampling lie in selecting information-rich cases for study". Semi-structured-focused-group interviews will help seek elaborations about participants' experiences and be designed to elicit interviewees' unobservable views and perspectives. The reason for using semi-structured-focused-group interviews is that unstructured interviews may pose uncontrollable problems such as out-of-the-topic conversation or digression and that structured interviews provide no flexibility as the interviewees are restricted to predetermined questions.

Moreover, they can trigger interaction among the participants and bring group interaction into enriched information. Interview questions were 
constructed based on the experiences in practicum, reflecting the participants' perceived difficulties and challenges pre-service student teachers were experiencing throughout the teaching practicum period. During the interviews, the audio recording and noting were applied to facilitate the transcription and the interpretation of the interviews.

\section{Data Analysis}

To answer research question 1, data gathered from the questionnaire were analysed using descriptive statistics such as frequencies and mean scores. The software Statistical Package for the Social Sciences (SPSS) was used in the data analysis. The criteria for interpreting the mean scores have been developed based on class interval calculation (Ruangprapun, 2000). The class interval is calculated by subtracting the maximum score with the minimum score and then dividing them with the number of scales; therefore, the class interval, in this case, is 0.80 . The criteria of the interpretation of mean scores are illustrated in Table 2. In the qualitative approach, thematic content analysis was employed with the interview transcriptions and an open-ended question in the questionnaire to find the common patterns across the data obtained.

Table 2: The Criteria of the Interpretation of Mean Scores

\begin{tabular}{|c|c|}
\hline Range & Interpretation \\
\hline $4.21-5.00$ & Strongly agree \\
\hline $3.41-4.20$ & Agree \\
\hline $2.61-3.40$ & Neutral \\
\hline $1.81-2.60$ & Disagree \\
\hline $1.00-1.80$ & Strongly disagree \\
\hline
\end{tabular}

To answer the second research question of whether or not there are statistical differences of pre-service teachers' challenges and difficulties related to their teaching levels (i.e., early childhood, primary school, and secondary school levels, mean scores and standard deviations were calculated and the results of One-Way ANOVA were extracted to determine whether a different independent variable (i.e., teaching levels) had any significant effects on challenges during teaching practicum.

\section{Ethical Considerations}

The participants were informed of the purpose of this study through the process of consent. All participants understood that participating in this study was voluntary, and they could decide to withdraw at any time. Furthermore, they all understood that no identification of the participants could be made as their identity is completely anonymous.

\section{Findings}

Table 3, it demonstrates that the participants seemed to agree with the positive items and disagree with the negative items. However, concerning designing lesson plans and managing the classrooms, most students appeared to be unable to decide whether they agreed or not. To able to discuss all issues, each item is illustrated in the following tables.

In this study, the findings from the questionnaire are demonstrated based on 4 main parts of the questionnaire: 1) communication factors, 2) instructional factors, 3) student-related factors, and 4) support-related factors. Then some findings from the follow-up interview help elaborate some findings from the questionnaire.

Table 3: Ranked Means of Each Item in the Questionnaire

\begin{tabular}{|l|c|c|c|}
\hline & Mean & S.D & Interpretation \\
\hline HF3: School mentors encouraged me during teaching practicum & 4.35 & .923 & Strongly Agree \\
\hline HF2: School mentors always gave advice concerning teaching & 4.32 & .904 & Strongly Agree \\
\hline HF1: I always received advice from my school mentor & 4.27 & .921 & Strongly Agree \\
\hline HF5: I always received advice from my supervisor & 4.22 & .962 & Strongly Agree \\
\hline HF6: I always received advice and help from my friends & 4.15 & 1.007 & Agree \\
\hline HF4: My supervisors always gave help & 4.12 & 1.057 & Agree \\
\hline SF2: I have good rapport with my students & 4.00 & .940 & Agree \\
\hline IF1: I could make the lesson interesting for students & 3.56 & .948 & Agree \\
\hline
\end{tabular}


SHANLAX

International Journal of Education

\begin{tabular}{|l|c|c|c|}
\hline IF9: I could adopt many kinds of teaching methods in class & 3.42 & 1.013 & Agree \\
\hline IF8: I could design lesson plans effectively & 3.18 & 1.003 & Neutral \\
\hline SF1: I think I could not control the class & 2.74 & 1.037 & Neutral \\
\hline SF3: I am not confident when teaching in a mixed ability class & 2.68 & 1.075 & Neutral \\
\hline IF2: I feel uncomfortable when teaching in a big class & 2.65 & 1.204 & Neutral \\
\hline CF3: I am worried about communication with school administrators & 2.64 & 1.238 & Neutral \\
\hline IF3: I feel worried when teaching in a mixed-ability class & 2.64 & 1.151 & Neutral \\
\hline IF7: I am not confident when giving feedback to students & 2.50 & 1.016 & Disagree \\
\hline CF1: I am worried about communication with my supervisor & 2.46 & 1.181 & Disagree \\
\hline IF6: I could not manage classroom time appropriately & 2.33 & .949 & Disagree \\
\hline IF5: I am not confident in teaching & 2.31 & .984 & Disagree \\
\hline IF4: I am not confident when explaining the lesson to students & 2.24 & .983 & Disagree \\
\hline CF2: I am worried about communication with my students & 2.03 & 1.044 & Disagree \\
\hline CF4: I am worried about communication with my school mentor & 1.99 & 1.111 & Disagree \\
\hline SC5: I feel tired every time I go to teach & 1.92 & 1.003 & Disagree \\
\hline HF7: I did not receive any support & 1.91 & 1.311 & Disagree \\
\hline SF4: I do not want to go to school because of students & 1.78 & 1.040 & Strongly Disagree \\
\hline CF5: I am worried about communication with my friends at the same school & 1.74 & .932 & Strongly Disagree \\
\hline
\end{tabular}

Table 4: Communication Factors (CF)

\begin{tabular}{|c|l|c|c|c|c|c|c|c|}
\hline $\begin{array}{r}\text { CF } \\
\text { No. }\end{array}$ & \multicolumn{1}{|c|}{ Statements } & $\begin{array}{l}\text { Strongly } \\
\text { Disagree }\end{array}$ & Disagree & Un-decide & Agree & $\begin{array}{c}\text { Strongly } \\
\text { Agree }\end{array}$ & Mean & Meaning \\
\hline 1 & $\begin{array}{l}\text { I am worried about } \\
\text { communication with my } \\
\text { supervisor }\end{array}$ & $23.10 \%$ & $35.90 \%$ & $17.90 \%$ & $17.90 \%$ & $5.10 \%$ & 2.46 & Disagree \\
\hline 2 & $\begin{array}{l}\text { I am worried about } \\
\text { communication with my } \\
\text { students }\end{array}$ & $39.70 \%$ & $30.80 \%$ & $16.70 \%$ & $12.80 \%$ & - & 2.03 & Disagree \\
\hline 3 & $\begin{array}{l}\text { I am worried about } \\
\text { communication with school } \\
\text { administrators }\end{array}$ & $20.50 \%$ & $28.20 \%$ & $28.20 \%$ & $12.80 \%$ & $10.30 \%$ & 2.64 & Neutral \\
\hline 4 & $\begin{array}{l}\text { I am worried about } \\
\text { communication with my } \\
\text { school mentor }\end{array}$ & $43.60 \%$ & $30.80 \%$ & $10.30 \%$ & $14.10 \%$ & $1.30 \%$ & 1.99 & Disagree \\
\hline 5 & $\begin{array}{l}\text { I am worried about } \\
\text { communication with my } \\
\text { friends at the same school }\end{array}$ & $50.00 \%$ & $33.30 \%$ & $10.30 \%$ & $5.10 \%$ & $1.30 \%$ & 1.74 & $\begin{array}{l}\text { Strongly } \\
\text { Disagree }\end{array}$ \\
\hline
\end{tabular}

As seen in Table 4 concerning communication factors, most students were not worried about communication with their supervisors (59.00\%), with their students $(70.50 \%)$, with their school mentors $(74.40 \%)$, and their friends at the same school $(83.30 \%)$ respectively. However, on the continuum line, some students could not decide whether or not they were worried about talking with school administrators. Still, most of them (48.70\%) moved towards disagreeing with such a statement.

Despite some favorable comments on communication factors, some students reported some concerns in the interview sessions as follows:

"I think both university supervisors and school mentors should care of us more. They never even asked us anything" (S7) 
"University supervisors should communicate with us more. I don't know who to consult with." (S8)

"I am very nervous when talking with my school mentor as she doesn't seem to be open to me. I am afraid that I would do something she doesn't like." (S9)
"I don't know how to talk or communicate with my school mentor. It was one that she asked me if she could keep all of my hand-made teaching materials for her next academic year. Can I reject her? How? It's all my own money." (S16)

Table 5: Instructional Factors (IF)

\begin{tabular}{|c|l|c|c|c|c|c|c|c|}
\hline $\begin{array}{c}\text { IF } \\
\text { No. }\end{array}$ & \multicolumn{1}{|c|}{ Statements } & $\begin{array}{l}\text { Strongly } \\
\text { Disagree }\end{array}$ & Disagree & Undecide & Agree & $\begin{array}{c}\text { Srtongly } \\
\text { Agree }\end{array}$ & MEAN & Meaning \\
\hline 1 & $\begin{array}{l}\text { I could make the lesson } \\
\text { interesting for students }\end{array}$ & $3.80 \%$ & $7.70 \%$ & $29.50 \%$ & $46.20 \%$ & $12.80 \%$ & 3.56 & Agree \\
\hline 2 & $\begin{array}{l}\text { I feel uncomfortable when } \\
\text { teaching in a big class }\end{array}$ & $19.20 \%$ & $32.10 \%$ & $17.90 \%$ & $25.60 \%$ & $5.10 \%$ & 2.65 & Neutral \\
\hline 3 & $\begin{array}{l}\text { I feel worried when } \\
\text { teaching in a mixed- } \\
\text { ability class }\end{array}$ & $16.70 \%$ & $35.90 \%$ & $17.90 \%$ & $25.60 \%$ & $3.80 \%$ & 2.64 & Neutral \\
\hline 4 & $\begin{array}{l}\text { I am not confident when } \\
\text { explaining the lesson to } \\
\text { students }\end{array}$ & $21.80 \%$ & $46.20 \%$ & $20.50 \%$ & $9.00 \%$ & $2.60 \%$ & 2.24 & Disagree \\
\hline 5 & $\begin{array}{l}\text { I am not confident in } \\
\text { teaching }\end{array}$ & $20.50 \%$ & $42.30 \%$ & $25.60 \%$ & $9.00 \%$ & $2.60 \%$ & 2.31 & Disagree \\
\hline 6 & $\begin{array}{l}\text { I could not manage } \\
\text { classroom time } \\
\text { appropriately }\end{array}$ & $17.90 \%$ & $44.90 \%$ & $24.40 \%$ & $11.50 \%$ & $1.30 \%$ & 2.33 & Disagree \\
\hline 7 & $\begin{array}{l}\text { I am not confident when } \\
\text { giving feedback to } \\
\text { students }\end{array}$ & $16.70 \%$ & $35.90 \%$ & $30.80 \%$ & $14.10 \%$ & $2.60 \%$ & 2.50 & Disagree \\
\hline 8 & $\begin{array}{l}\text { I could design lesson } \\
\text { plans effectively }\end{array}$ & $2.60 \%$ & $24.40 \%$ & $35.90 \%$ & $26.90 \%$ & $10.30 \%$ & 3.18 & Neutral \\
\hline 9 & $\begin{array}{l}\text { I could adopt many kinds } \\
\text { of teaching methods in } \\
\text { class }\end{array}$ & $5.10 \%$ & $9.00 \%$ & $38.50 \%$ & $33.30 \%$ & $14.10 \%$ & 3.42 & Agree \\
\hline
\end{tabular}

As seen in Table 5 concerning instructional factors, most students disagreed with the negative statements, indicating that they were not confident when explaining the lesson to students $(68.00 \%)$, were not confident in teaching $(62.80 \%)$, were not confident when giving feedback to students $(52.60 \%)$, could not manage classroom time appropriately $(62.80 \%)$, felt uncomfortable when teaching in a big class $(51.30 \%)$, and felt worried when teaching in a mixed-ability class $(52.60 \%)$. On the other hand, most of them reported that they could make the lesson interesting for their students $(59.00 \%)$ and could adopt many teaching methods in class $(47.40 \%)$. However, comparing the two ends, some students could not decide whether or not they could design lesson plans effectively, but most of them (37.20\%) moved towards disagreeing with such a statement.

Despite some favorable comments on instructional factors, some students reported some concerns in the interview sessions as follows:

"Some content is too complicated to teach. I mean, it is very difficult to adopt various teaching activities and I don't know-how, thus I ended up giving a lecture so that I could complete the lesson in time." (S1)

"There were times I thought I could design effective lesson plans and deliver them effectively, as 
I asked my students if they couldn't follow me, and they said no. When it comes to exercises, many still failed." (S3)

"I don't feel uncomfortable teaching a large class. I feel like I could manage it well enough" (S2)

"Some teaching theories we have learned are not practical. Some of them are not applicable in our context, or I don't know how to implement them correctly. Our faculty should pay more attention to how to implement them." (S7)

"I had a problem concerning answering students' answers. Sometimes, I could not answer their questions and I did not know what to do." (S12)

Table 6: Student-related Factors (SF)

\begin{tabular}{|c|l|c|c|c|c|c|c|c|}
\hline $\begin{array}{c}\text { CF } \\
\text { No. }\end{array}$ & \multicolumn{1}{|c|}{ Statements } & $\begin{array}{c}\text { Strongly } \\
\text { Disagree }\end{array}$ & Disagree & Un-decide & Agree & $\begin{array}{c}\text { Strongly } \\
\text { Agree }\end{array}$ & Mean & Meaning \\
\hline 1 & $\begin{array}{l}\text { I think I could not control } \\
\text { the class }\end{array}$ & $10.30 \%$ & $34.60 \%$ & $29.50 \%$ & $21.80 \%$ & $3.80 \%$ & 2.74 & Disagree \\
\hline 2 & $\begin{array}{l}\text { I have good rapport with } \\
\text { my students }\end{array}$ & $3.80 \%$ & $3.80 \%$ & $9.00 \%$ & $55.10 \%$ & $28.20 \%$ & 4.00 & Agree \\
\hline 3 & $\begin{array}{l}\text { I am not confident when } \\
\text { teaching in a mixed ability } \\
\text { class }\end{array}$ & $12.80 \%$ & $35.90 \%$ & $25.60 \%$ & $21.80 \%$ & $3.80 \%$ & 2.68 & Neutral \\
\hline 4 & $\begin{array}{l}\text { I do not want to go to } \\
\text { school because of students }\end{array}$ & $52.60 \%$ & $29.50 \%$ & $6.40 \%$ & $10.30 \%$ & $1.30 \%$ & 1.78 & Disagree \\
\hline 5 & $\begin{array}{l}\text { I feel tired every time I go } \\
\text { to teach }\end{array}$ & $41.00 \%$ & $37.20 \%$ & $11.50 \%$ & $9.00 \%$ & $1.30 \%$ & 1.92 & $\begin{array}{l}\text { Strongly } \\
\text { Disagree }\end{array}$ \\
\hline
\end{tabular}

As seen in Table 6 concerning student-related factors, most students disagreed with the negative statements, indicating that they could not control the class $(44.90 \%)$, were not confident in teaching $(62.80 \%)$, did not want to go to school because of the students $(82.10 \%)$, and felt tired every time they went to teach $(78.20 \%)$. In a positive station, most students $(83.30 \%)$ agreed that they had a good rapport with their students. However, comparing the two ends, some students could not decide whether they were not confident when teaching in a mixed ability class. Still, most of them (48.70\%) moved towards disagreeing with such a statement.

Despite some positive comments on studentrelated factors, some students reported some concerns in the interview sessions as follows:

"One of the most difficult challenges I am facing is how to deal with special children. In my class, there are two special children. I don't know how to deal with them properly. We are never taught to do so. I am just lost." (S7)

"I also have special children in my class. I don't know how to deal with them either. Frankly speaking, I know it's their nature, but they just disturb my teaching. I wish I could learn how to deal with them." (S8)

"I think I cannot control the class. Students don't seem to pay attention to my teaching, and they are always loud. What I could do was speaking louder. I know it is not right, but I don't know what I can do." (S6)

"Many students of mine never submitted their work. I don't know what to do." (S2)

"Some students treat me as a friend. They do not even pay respect to me” (S13)

Table 7: Support-related Factors (HF)

\begin{tabular}{|c|c|c|c|c|c|c|c|c|}
\hline $\begin{array}{c}\text { CF } \\
\text { No. }\end{array}$ & Statements & $\begin{array}{c}\text { Strongly } \\
\text { Disagree }\end{array}$ & Disagree & Un-decide & Agree & $\begin{array}{c}\text { Strongly } \\
\text { Agree }\end{array}$ & Mean & Meaning \\
\hline 1 & $\begin{array}{l}\text { I always received advice } \\
\text { from my school mentor }\end{array}$ & $1.30 \%$ & $3.80 \%$ & $12.80 \%$ & $30.80 \%$ & $51.30 \%$ & 4.27 & $\begin{array}{c}\text { Strongly } \\
\text { Agree }\end{array}$ \\
\hline
\end{tabular}




\begin{tabular}{|c|l|c|c|c|c|c|c|c|}
\hline 2 & $\begin{array}{l}\text { School mentors always } \\
\text { gave advice concerning } \\
\text { teaching }\end{array}$ & $1.30 \%$ & $2.60 \%$ & $14.10 \%$ & $26.90 \%$ & $55.10 \%$ & 4.32 & $\begin{array}{c}\text { Strongly } \\
\text { Agree }\end{array}$ \\
\hline 3 & $\begin{array}{l}\text { School mentors } \\
\text { encouraged me during } \\
\text { teaching practicum }\end{array}$ & $1.30 \%$ & $3.80 \%$ & $11.50 \%$ & $25.60 \%$ & $57.70 \%$ & 4.35 & $\begin{array}{c}\text { Strongly } \\
\text { Agree }\end{array}$ \\
\hline 4 & $\begin{array}{l}\text { My supervisors always } \\
\text { gave me help }\end{array}$ & $2.60 \%$ & $6.40 \%$ & $15.40 \%$ & $28.20 \%$ & $47.40 \%$ & 4.12 & Agree \\
\hline 5 & $\begin{array}{l}\text { I always received advice } \\
\text { from my supervisor }\end{array}$ & $2.60 \%$ & $2.60 \%$ & $14.10 \%$ & $32.10 \%$ & $48.70 \%$ & 4.22 & $\begin{array}{c}\text { Strongly } \\
\text { Agree }\end{array}$ \\
\hline
\end{tabular}

As seen in Table 7 concerning support-related factors, most students agreed with the statements in this aspect, indicating that they always received advice from their mentors $(82.10 \%)$, their school mentors always advised teaching $(82.00 \%)$, their school mentors encouraged them during their teaching practicum $(83.30 \%)$, they university supervisors always gave them help (75.60\%). They always received advice from their university supervisor $(80.80 \%)$.

Despite some favorable comments on supportrelated factors, some students reported some concerns in the interview sessions as follows:

"I wish my school mentor would be more openminded. She never listened to me." (S10)

"My school mentor seems like she always keeps something with her. When there is something I should know, she never tells me." (S9)
"My school mentor never comes to observe my teaching and gives advice. I am like being thrown into deep water. Is it supposed to be their responsibility?" (S11)

"My university supervisor never gives me any advice. She just visited us, observed us, and left. I don't even know how well I did." (S12)

"My school mentor asked me to do their work. It's not supposed to be my job. I don't know how to refuse her, as she plays a key role in assessing me." (S14)

To answer research question 2, One-Way ANOVA was analyzed. ANOVA results showed significant differences between teaching levels $\mathrm{F}(2,78)=31.78, \mathrm{p}<.05$. Scheffe post hoc tests showed differences between teaching levels (Table 8).

Table 8: The Relationship between Teaching Levels and Challenges

\begin{tabular}{|c|c|c|c|c|c|c|}
\hline \multicolumn{7}{|c|}{ ANOVA } \\
\hline & & Sum of squares & df & Mean square & $\mathbf{F}$ & Sig. \\
\hline \multirow{3}{*}{$\mathrm{CF} 1$} & Between Groups & .824 & 2 & .412 & \multirow{2}{*}{.290} & \multirow{2}{*}{.749} \\
\hline & Within Groups & 106.561 & 75 & 1.421 & & \\
\hline & Total & 107.385 & 77 & & & \\
\hline \multirow{3}{*}{ CF2 } & Between Groups & .991 & 2 & .495 & \multirow{2}{*}{.448} & \multirow{2}{*}{.641} \\
\hline & Within Groups & 82.958 & 75 & 1.106 & & \\
\hline & Total & 83.949 & 77 & & & \\
\hline \multirow{3}{*}{ CF3 } & Between Groups & 1.683 & 2 & .842 & \multirow{2}{*}{.543} & \multirow{2}{*}{.583} \\
\hline & Within Groups & 116.266 & 75 & 1.550 & & \\
\hline & Total & 117.949 & 77 & & & \\
\hline \multirow{3}{*}{ CF4 } & Between Groups & .342 & 2 & .171 & \multirow{2}{*}{.136} & \multirow{2}{*}{.873} \\
\hline & Within Groups & 94.645 & 75 & 1.262 & & \\
\hline & Total & 94.987 & 77 & & & \\
\hline
\end{tabular}


SHANLAX

International Journal of Education

\begin{tabular}{|c|c|c|c|c|c|c|}
\hline \multirow{3}{*}{ CF5 } & Between Groups & .507 & 2 & .254 & \multirow{2}{*}{.287} & \multirow{2}{*}{.752} \\
\hline & Within Groups & 66.365 & 75 & .885 & & \\
\hline & Total & 66.872 & 77 & & & \\
\hline \multirow{3}{*}{ IF 1} & Between Groups & 5.236 & 2 & 2.618 & \multirow{2}{*}{3.071} & \multirow{2}{*}{.052} \\
\hline & Within Groups & 63.944 & 75 & .853 & & \\
\hline & Total & 69.179 & 77 & & & \\
\hline \multirow{3}{*}{ IF2 } & Between Groups & .706 & 2 & .353 & \multirow{2}{*}{.239} & \multirow{2}{*}{.788} \\
\hline & Within Groups & 110.948 & 75 & 1.479 & & \\
\hline & Total & 111.654 & 77 & & & \\
\hline \multirow{3}{*}{ IF3 } & Between Groups & 4.168 & 2 & 2.084 & \multirow{2}{*}{1.598} & \multirow{2}{*}{.209} \\
\hline & Within Groups & 97.781 & 75 & 1.304 & & \\
\hline & Total & 101.949 & 77 & & & \\
\hline \multirow{3}{*}{ IF4 } & Between Groups & 2.788 & 2 & 1.394 & \multirow{2}{*}{1.460} & \multirow{2}{*}{.239} \\
\hline & Within Groups & 71.584 & 75 & .954 & & \\
\hline & Total & 74.372 & 77 & & & \\
\hline \multirow{3}{*}{ IF5 } & Between Groups & 1.771 & 2 & .885 & \multirow{2}{*}{.912} & \multirow{2}{*}{.406} \\
\hline & Within Groups & 72.845 & 75 & .971 & & \\
\hline & Total & 74.615 & 77 & & & \\
\hline \multirow{3}{*}{ IF6 } & Between Groups & .730 & 2 & .365 & \multirow{2}{*}{.399} & \multirow{2}{*}{.672} \\
\hline & Within Groups & 68.604 & 75 & 915 & & \\
\hline & Total & 69.333 & 77 & & & \\
\hline \multirow{3}{*}{ IF8 } & Between Groups & 5.208 & 2 & 2.604 & \multirow{2}{*}{2.702} & \multirow{2}{*}{.074} \\
\hline & Within Groups & 72.279 & 75 & .964 & & \\
\hline & Total & 77.487 & 77 & & & \\
\hline \multirow{3}{*}{ IF9 } & Between Groups & 6.922 & 2 & 3.461 & 3600 & 032 \\
\hline & Within Groups & 72.116 & 75 & .962 & 0.000 & \\
\hline & Total & 79.038 & 77 & & & \\
\hline & Between Groups & 3.539 & 2 & 1.769 & 1673 & 105 \\
\hline SF1 & Within Groups & 79.333 & 75 & 1.058 & $1.6 / 3$ & .195 \\
\hline & Total & 82.872 & 77 & & & \\
\hline & Between Groups & 1.826 & 2 & .913 & 1025 & 260 \\
\hline SF2 & Within Groups & 66.174 & 75 & .882 & 1.035 & (J00 \\
\hline & Total & 68.000 & 77 & & & \\
\hline & Between Groups & 1.755 & 2 & .878 & 755 & 474 \\
\hline SF3 & Within Groups & 87.232 & 75 & 1.163 & 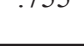 & .4717 \\
\hline & Total & 88.987 & 77 & & & \\
\hline & Between Groups & 3.290 & 2 & 1.645 & 1542 & 221 \\
\hline SF4 & Within Groups & 80.005 & 75 & 1.067 & 1.042 & .221 \\
\hline & Total & 83.295 & 77 & & & \\
\hline & Between Groups & 4.440 & 2 & 2.220 & 0270 & 110 \\
\hline SF5 & Within Groups & 73.098 & 75 & .975 & 2.218 & .110 \\
\hline & Total & 77.538 & 77 & & & \\
\hline
\end{tabular}


International Journal of Education

\begin{tabular}{|c|c|c|c|c|c|c|}
\hline \multirow{3}{*}{ HF1 } & Between Groups & .729 & 2 & .364 & \multirow{2}{*}{.423} & \multirow{2}{*}{.657} \\
\hline & Within Groups & 64.617 & 75 & .862 & & \\
\hline & Total & 65.346 & 77 & & & \\
\hline \multirow{3}{*}{ HF2 } & Between Groups & 1.784 & 2 & .892 & \multirow{2}{*}{1.093} & \multirow{2}{*}{.341} \\
\hline & Within Groups & 61.204 & 75 & .816 & & \\
\hline & Total & 62.987 & 77 & & & \\
\hline \multirow{3}{*}{ HF3 } & Between Groups & 2.531 & 2 & 1.266 & \multirow{2}{*}{1.504} & \multirow{2}{*}{.229} \\
\hline & Within Groups & 63.123 & 75 & .842 & & \\
\hline & Total & 65.654 & 77 & & & \\
\hline \multirow{3}{*}{ HF4 } & Between Groups & 1.984 & 2 & .992 & \multirow{2}{*}{.886} & \multirow{2}{*}{.417} \\
\hline & Within Groups & 83.978 & 75 & 1.120 & & \\
\hline & Total & 85.962 & 77 & & & \\
\hline \multirow{3}{*}{ HF5 } & Between Groups & 4.111 & 2 & 2.055 & \multirow{2}{*}{2.294} & \multirow{2}{*}{.108} \\
\hline & Within Groups & 67.184 & 75 & .896 & & \\
\hline & Total & 71.295 & 77 & & & \\
\hline \multirow{3}{*}{ HF6 } & Between Groups & 2.576 & 2 & 1.288 & \multirow{2}{*}{1.278} & \multirow{2}{*}{.285} \\
\hline & Within Groups & 75.578 & 75 & 1.008 & & \\
\hline & Total & 78.154 & 77 & & & \\
\hline \multirow{3}{*}{ HF7 } & Between Groups & 2.632 & 2 & 1.316 & \multirow{2}{*}{.761} & \multirow{2}{*}{.471} \\
\hline & Within Groups & 129.740 & 75 & 1.730 & & \\
\hline & Total & 132.372 & 77 & & & \\
\hline
\end{tabular}

$* \mathrm{p}<.05$

As seen in Table 8 above, there is only one factor in Table 9. The possible reason for this is that the (IF9: I could adopt many kinds of teaching methods nature of students and teaching content in early in class) that appears to indicate statistical differences childhood and primary school levels are different; among the three teaching levels $(\mathrm{p}<.05)$. To find out, thus, teaching methods might be limited to some Scheffe post hoc tests revealed differences between extent. early childhood and primary school levels, as shown

Table 9: Differences between Teaching Levels Evaluated by Scheffe Post Hoc Tests

\begin{tabular}{|c|c|c|c|c|c|c|c|}
\hline & & & & & & $\begin{array}{r}95 \% \mathrm{Cc} \\
\text { Int }\end{array}$ & $\begin{array}{l}\text { idence } \\
\text { al }\end{array}$ \\
\hline $\begin{array}{l}\text { Dependent } \\
\text { Variable }\end{array}$ & (I) Level & (J) Level & $\begin{array}{c}\text { Mean } \\
\text { Difference (I-J) }\end{array}$ & Std. Error & Sig. & $\begin{array}{l}\text { Lower } \\
\text { Bound }\end{array}$ & $\begin{array}{l}\text { Upper } \\
\text { Bound }\end{array}$ \\
\hline \multirow{4}{*}{ IF9 } & \multirow{2}{*}{$\begin{array}{c}\text { Early } \\
\text { Childhood }\end{array}$} & Primary School & $-.842 *$ & .314 & .032 & -1.63 & -.06 \\
\hline & & Secondary School & -.436 & .270 & .277 & -1.11 & .24 \\
\hline & \multirow{2}{*}{$\begin{array}{l}\text { Primary } \\
\text { School }\end{array}$} & Early Childhood & $.842 *$ & .314 & .032 & .06 & 1.63 \\
\hline & & Secondary School & .406 & .274 & .339 & -.28 & 1.09 \\
\hline \multirow{2}{*}{ IF9 } & \multirow{2}{*}{$\begin{array}{c}\text { Secondary } \\
\text { School }\end{array}$} & Early Childhood & .436 & .270 & .277 & -.24 & 1.11 \\
\hline & & Primary School & -.406 & .274 & .339 & -1.09 & .28 \\
\hline
\end{tabular}

The mean difference is significant at the 0.05 level.* 


\section{Discussion}

In this study, there are two research questions to be discussed. To begin with, research question 1 "What are the problems or challenges Thai pre-service student teachers to experience during their teaching practicum?" will be discussed. Based on the findings from a questionnaire and interviews, it revealed that pre-service student teachers faced challenges and difficulties to some extent. Such challenges include 4 factors: communication factors, instructional factors, student-related factors, \& support-related factors.

First, based on the findings from a questionnaire, most participants did not have any challenges regarding communication with people involved in their teaching practicum. However, some of the participants faced some challenges concerning communicating with school mentors or university supervisors. This finding is consistent with the study by Shalawati and Hadijah (2018), demonstrating that some pre-service student teachers were not brave enough to openly talk to supervisors or mentors.

Second, most of the participants did not have any challenges regarding instructions. However, many participants reported that they had challenges in teaching, especially applying theories into practice. Some of them believed that their challenges were concerned with the application and implementation of some teaching theories, possibly due to false clarity. This finding corroborates with Blaik Hourani (2013) which points out inconsistencies between theories and practice. Moreover, Genç (2016) found a gap between their knowledge of classroom practices from university education and the reality of the classroom. Concerning this issue, more explicit instructions on teaching theories and their implementation should be provided.

Third, most of the participants reported that they did not have any challenges regarding their students. However, some participants reported having challenges concerning how to deal with special children. This finding is in line with Forlin et al. (2009), demonstrating that many educators face the most discomfort and lack confidence in including children with special needs in their teaching. With this concern, special consideration on dealing with them should be carefully given to addressing this issue in teacher preparation programs.
Fourth, most of the participants did not have any challenges regarding supports. However, many participants expressed in the interviews that they did not receive supports from school mentors as well as, for some, university supervisors. This seems to accord with the study by Mtika's (2011) study indicating that some pre-service student teachers lack the formal structure of support and collaboration from school mentors even though positive interactions between mentors and preservice student teachers can contribute a great deal towards enhanced professional development (Sivan \& Chan, 2009). Wang (2001) also suggests that the extent to which pre-service student teachers interact with school mentors varies depending on supportive structures such as schools and regular classroom observations. Moreover, Guarino, et al., (2006) demonstrate that pre-service student teachers who gain appropriate support from school mentors during their teaching practicum tend to have a stronger commitment to teaching.

To discuss the second research question, "Are there statistical differences of pre-service teachers' challenges and difficulties related to their teaching levels (i.e., early childhood, primary school, and secondary school levels)?", One-Way ANOVA was adopted to yield the results. The finding discovered significant differences between teaching levels. To elaborate, the one factor (IF9: I could adopt many kinds of teaching methods in class) appears to indicate statistical differences between early childhood and primary school levels. To support this finding, File and Gullo (2002) demonstrate that early childhood teachers and primary school teachers had different thoughts towards teaching activities, as they both have a tradition of different teaching practices (Goldstein, 1997). Early childhood activities are child-directed and play-oriented while primary school activities put a traditionally heavier reliance on teacher-direction and discrete-content areas. Also, Buchanan, et al., (1998) and Smith (1997) also indicate that early childhood teachers appeared to favor less frequent use of teacher-directed activities than primary school teachers. 


\section{Conclusion}

The study explored the perceptions pre-service student teachers had about their challenges and difficulties that hindered their teaching practices. This study employed a convergent mixed-methods approach, which adopted a questionnaire and semistructured focused-group-interviews as the research instruments. The participants of this small-scale study included 78 B.Ed. Students at a university in Thailand. There were 78 participants in a quantitative phase, while 17 of them participated in a semi-structured-focus-group interview. The findings demonstrated around 4 dimensions of various constraints and challenges. This embodied: communication factors, instructional factors, studentrelated factors, and support-related factors. Based on the findings from the questionnaire, the majority of the participants appeared to disagree that they had challenges during teaching practicum. However, from the interviews, many participants reported having challenges and difficulties concerning the four dimensions of challenges. Based on OneWay ANOVA, most students appeared to face similar challenges. However, pre-service student teachers at early childhood and primary school levels highlighted the different challenges which they encountered during their practicum experience concerning various teaching methods used in their lessons.

However, there are some limitations in this study to be acknowledged. First, the number of participants in this study is rather small; only 78 participants in a questionnaire session and only 17 took part in the semi-structure-focus-group interviews. Therefore, it would be inappropriate to generalize the findings from a small group of participants as a representative of the Thai pre-service student teachers throughout Thailand. It is, however, in the hope that readers could relate the findings to their contexts. Second, this study conducted data collection only through a questionnaire and a semi-structured-focusgroup interview. Although the follow-up interview provided ample data on their challenges, the results might not cover the overall aspects of teaching practicums, especially in classroom contexts. For example, classroom observations could do. Moreover, a self-report method (such as a self-report questionnaire) could cause a social desirability bias. The respondents tend to inaccurately report to provide a favorable image of themselves to gain social acceptance (Nederhof, 1985).

\section{References}

Allen, Jeanne M. "Valuing Practice Over Theory: How Beginning Teachers Re-orient their Practice in the Transition from the University to the Workplace." Teaching and Teacher Education, vol. 25, no. 5, 2009, pp. 647-654.

Blaik Hourani, Rida. 'Pre-service Teachers' Reflection: Perception, Preparedness and Challenges." Reflective Practice, vol. 14, no. 1, 2013, pp. 12-30.

Buchanan, Teresa K., et al. "Predictors of the Developmental Appropriateness of the Beliefs and Practices of First, Second, and Third Grade Teachers." Early childhood research quarterly, vol. 13, no. 3, 1998, pp. 459-483.

Copland, Fiona, et al. "Challenges in Teaching English to Young Learners: Global Perspectives and Local Realities." TESOL Quarterly, vol. 48, no. 4, 2014, pp. 738-762.

Creswell, John W., and J. David Creswell. Research Design: Qualitative, Quantitative, and Mixed Methods Approaches. Sage, 2018.

Denzin, Norman K., and Yvonna S. Lincoln. Handbook of Qualitative Research. Sage, 2000.

File, Nancy, and Dominic F. Gullo. "A Comparison of Early Childhood and Elementary Education Students' Beliefs about Primary Classroom Teaching Practices." Early Childhood Research Quarterly, vol. 17, no. 1, 2002, pp. 126-137.

Forlin, Chris, et al. "Demographic Differences in Changing Pre-service Teachers' Attitudes, Sentiments and Concerns about Inclusive Education." International Journal of Inclusive Education, vol. 13, no. 2, 2009, pp. 195-209.

Gan, Zhengdong. "Learning to Teach English Language in the Practicum: What Challenges do Non-Native ESL Student Teachers Face?." Australian Journal of Teacher Education, vol. 38, no. 3, 2013. 
Genç, Zübeyde Sinem. "More Practice for PreService Teachers and More Theory for InService Teachers of English Language." Procedia - Social and Behavioral Sciences, 2016, pp. 677-683.

Goldstein, Lisa S. "Between a Rock and a Hard Place in the Primary Grades: The Challenge of Providing Developmentally Appropriate Early Childhood Education in an Elementary School Setting." Early Childhood Research Quarterly, vol. 12, no. 1, 1997, pp. 3-27.

Graham, Sue, and Christina Thornley. "Connecting Classrooms in Pre-Service Education: Conversations for Learning." Asia-Pacific Journal of Teacher Education, vol. 28, no. 3, 2000, pp. 235-245.

Guarino, Cassandra M., et al. "Teacher Recruitment and Retention: A Review of the Recent Empirical Literature." Review of Educational Research, vol. 76, no. 2, 2006, pp. 173-208.

Gujjar, Ajjaz Ahmed, et al. "An Evaluation of Teaching Practice: Practicum." Pakistan Journal of Commerce and Social Sciences, vol. 5, no. 2, 2011, pp. 302-318.

Hammad, S. "The Reality of Practicum in the Areas of Al-Quds Open University in Gaza Governorates from the perspective of students." Journal of the Islamic University, vol. 13, no. 1, 2005, pp. 155-193.

Hastings, Wendy. "Emotions and the Practicum: The Cooperating Teachers' Perspective." Teachers and Teaching, vol. 10, no. 2, 2004, pp. 135-148.

Jusoh, Z. Teaching Practicum: Student Teachers' Perspectives. 2013.

Kabilan, Muhammad Kamarul, and Raja Ida Raja Izzaham. "Challenges Faced and the Strategies Adopted by a Malaysian English Language Teacher during Teaching Practice." English Language Teaching, vol. 1, no. 1, 2008, pp. 87-95.

Maxwell, Joseph A. "Designing a Qualitative Study." Handbook of Applied Social Research Methods. Edited by Leonard Bickman, and Debra J. Rog, Sage, 1997, pp. 69-100.

Mtika, P. “Trainee Teachers' Experiences of Teaching Practicum: Issues, Challenges, and
New Possibilities." Africa Education Review, vol. 8, no. 3, 2011, pp. 551-567.

Mudra, Heri. "Pre-Service EFL Teachers' Experiences in Teaching Practicum in Rural Schools in Indonesia." The Qualitative Report, vol. 23, no. 2, 2018, pp. 319-344.

Mukminin, Amirul. "Acculturative Experiences among Indonesian Graduate Students in US Higher Education: Academic Shock, Adjustment, Crisis, and Resolution." Excellence in Higher Education, vol. 3, 2012, pp. 14-36.

Myles, Johanne, et al. "Teaching in Elementary School: Perceptions of Foreign-Trained Teacher Candidates on their Teaching Practicum." Teaching and Teacher Education, vol. 22, no. 2, 2006, pp. 233-245.

Nederhof, Anton J. "Methods of Coping with Social Desirability Bias: A Review." European Journal of Social Psychology, vol. 15, no. 3, 1985, pp. 263-280.

O’Neill, Sue, and Jennifer Stephenson. "Does Classroom Management Coursework Influence Pre-Service Teachers' Perceived Preparedness or Confidence?." Teaching and Teacher Education, vol. 28, no. 8, 2012, pp. 1131-1143.

Patton, Michael Quinn. Qualitative Evaluation and Research Methods. Sage, 1990.

Prihatin, Yoga, et al. "Challenges in Teaching English to Young Learners in Southern Thailand (A Case Study of Indonesian PreService Teachers' Perspectives)." Psychology and Education Journal, vol. 58, no. 2, 2021, pp. 6098-6107.

Punch, Keith F. Introduction to Social Research: Quantitative and Qualitative Approaches. Sage, 2014.

Pushkin, Dave. Teacher Training: A Reference Handbook. ABC-CLIO, 2001.

Rozelle, Jeffrey J., and Suzanne M. Wilson. "Opening the Black Box of Field Experiences: How Cooperating Teachers' Beliefs and Practices Shape Student Teachers' Beliefs and Practices." Teaching and Teacher Education, vol. 28, no. 8, 2012, pp. 1196-1205. 
Sammephet, Banchakarn, and Phalangchok Smith, Kari, and Lilach Lev-Ari. "The Place of the Wanphet. "Pre-Service Teachers' Anxiety and Anxiety Management during the First Encounter with Students in EFL classroom." Journal of Education and Practice, vol. 4, no. 2, 2013, pp. 78-87.

Sağlam, Gülderen. Perceived Roles, Responsibilities and Challenges of CT's in the Procedure of Teaching Practice Course in Practicum. Middle East Technical University, 2007.

Shalawati, and Sitti Hadijah. "Teaching Practicum Current Practices: Challenges and Opportunity." J-SHMIC: Journal of English for Academic, vol. 5, no. 1, 2018, pp. 113-123.

Sivan, Atara, and Dennis W.K. Chan. "The Roles of Supervised Teaching Practice and Peer Observation in Teacher Education in Hong Kong: Implications for Partnership." Teacher Development, vol. 13, 2009, pp. 251-266.

Practicum in Pre-Service Teacher Education: The Voice of the Students." Asia-Pacific Journal of Teacher Education, vol. 33, no. 3, 2005, pp. 289-302.

Smith, Kenneth E. “Student Teachers' Beliefs about Developmentally Appropriate Practice: Pattern, Stability, and the Influence of Locus of Control." Early Childhood Research Quarterly, vol. 12, no. 2, 1997, pp. 221-243.

Yunus, Melor Md, et al. "Understanding TESL PreService Teachers' Teaching Experiences and Challenges via Post-practicum Reflection Forms." Procedia - Social and Behavioral Sciences, vol. 9, 2010, pp. 722-728.

Zeichner, Ken. "Rethinking the Connections between Campus Courses and Field Experiences in College-and University-based Teacher Education." Journal of Teacher Education, vol. 61, no. 1-2, 2010, pp. 89-99.

\footnotetext{
Author Details

Pariwat Imsa-ard, Faculty of Education, Ramkhamhaeng University, Bangkok, Thailand,

Email ID: pariwat.i@rumail.ru.ac.th
}

Peerada Wichamuk, Faculty of Education, Ramkhamhaeng University, Bangkok, Thailand

Chain Chuanchom, Faculty of Education, Ramkhamhaeng University, Bangkok, Thailand 